\title{
Developing Clinical Genetics Diagnostic Skills: Van Der Hoeve-Waardenburg Syndrome
}

\author{
Aamir Jalal Al Mosawi ${ }^{1,2 *}$ \\ ${ }^{1}$ Senior Advisor Doctor, Baghdad Medical City, Iraq \\ ${ }^{2}$ Head, Iraq Headquarter of Copernicus Scientists International Panel, Baghdad, Iraq \\ *Corresponding author: Aamir Jalal Al Mosawi, Senior Advisor Doctor, Baghdad Medical City, Iraq \\ Head, Iraq Headquarter of Copernicus Scientists International Panel, Baghdad, Iraq
}

\begin{tabular}{|c|c|}
\hline ARTICLE INFO & ABSTRACT \\
\hline Received: 幽 November 10, 2020 & Citation: Aamir Jalal Al Mosawi. Developing Clinical Genetics Diagnostic Skills: Van \\
\hline Published: 豐 November 19, 2020 & $\begin{array}{l}\text { Der Hoeve-Waardenburg Syndrome. Biomed J Sci \& Tech Res 32(1)-2020. BJSTR. } \\
\text { MS.ID.005187. }\end{array}$ \\
\hline
\end{tabular}

\section{Mini Review}

There are many rare clinical syndromes and dysmorphic syndromes including genetic syndromes, and it is really difficult for many clinicians to equip themselves with adequate professional knowledge that help them to make an early diagnosis for many of the rare syndromes they may encounter [1-5]. We have previously published our pioneering huge and unique experiences with clinical genetics and dysmorphology in a plethora of publications. We have previously described a large number of rare disorders in Iraq [6-14], and we have also helped doctors in the diagnosis and publication of rare conditions observed in other countries [15]. The aim of this papers is to help practicing physicians in developing the diagnostic skills in the field of clinical syndromes by briefly reviewing a rare syndrome that have not been reported in Iraq, but it is associated with unique clinical characteristics that allow doctors who see the syndrome for the first time, capable of making an early diagnosis rather easily, by knowing few information about the syndrome. Van der Hoeve-Waardenburg syndrome is a rare genetic associated with unique clinical manifestations including a white forelock (Figure 1) or premature grayness of hair, heterochromia iridum (Figure 2) or sectoral heterochromia iridum (multiple colors in one eye), hypertelorism (Figure 2) or telecanthus which is also called dystopia canthorum (Figure 1), and congenital sensorineural hearing impairment $[16,17]$.

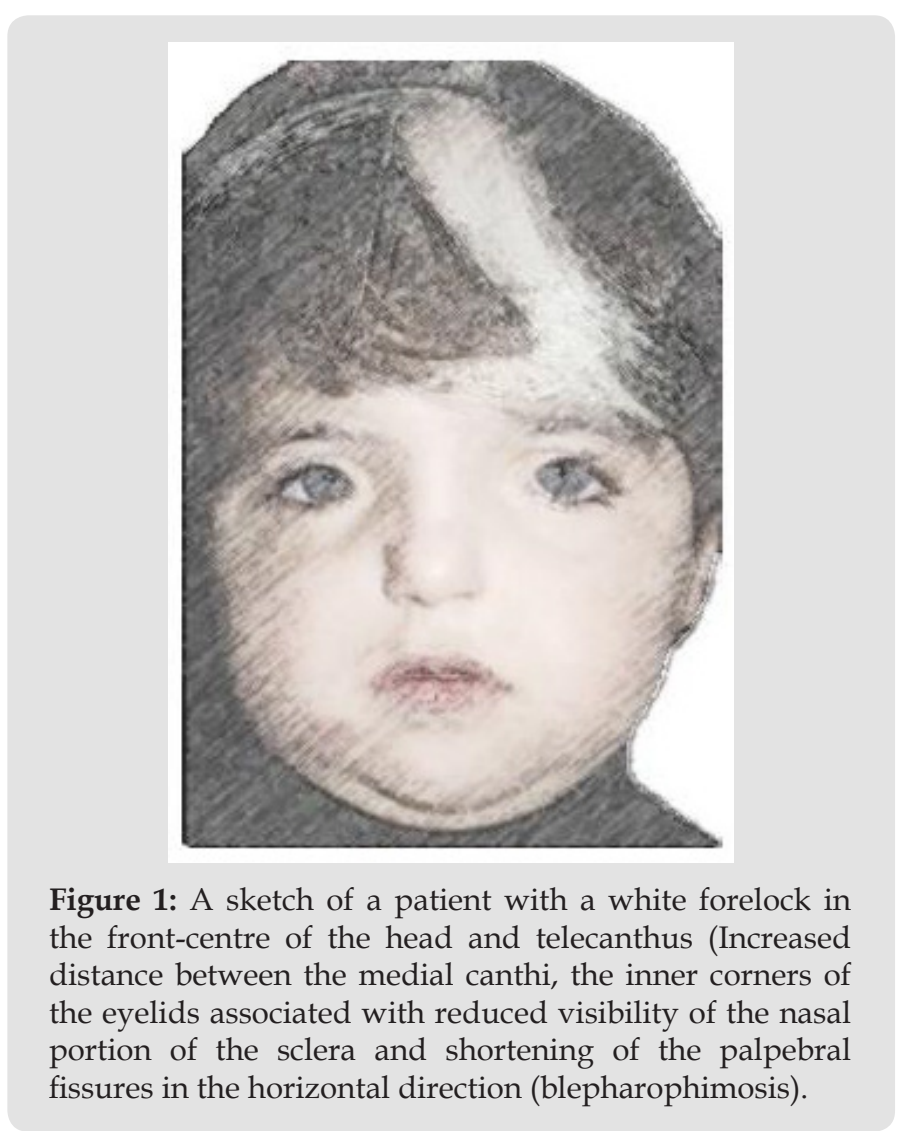




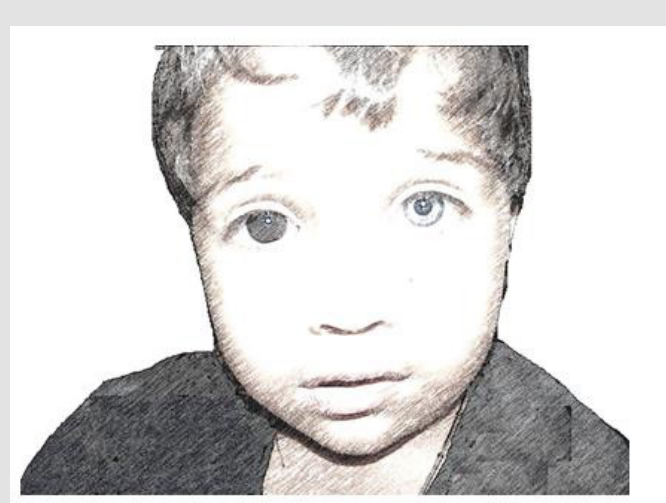

Figure 2: A sketch of a patient with heterochromia iridum, differently colored eyes and hypertelorism (Increased distance between the whole eyes; lateral displacement of the eyes, eyelids, and orbits).

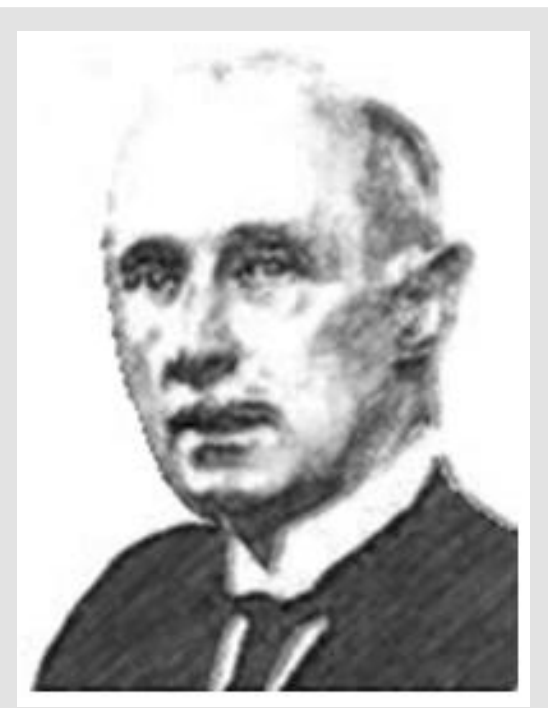

Figure 3: Jan van der Hoeve (April, 13, 1878-April, 26, 1952), a Dutch ophthalmologist who is best known for describing the concept of the phakomatoses, which is also called neuro-cutaneous syndromes.

Hammerschlag (1907) [18], and Urbantschitsch (1910) [19] reported the occurrence of heterochromia iridum in association with partial albinism and hearing loss, but without suggesting the possibility of a distinct clinical entity. In 1916, Jan van der Hoeve (Figure 3) reported a pair of 14 year-old monozygotic twin girls with congenital sensorineural hearing loss and dystopia canthorum [16]. In 1926, German physician Irmgard Mende reported a family of four generations from Berlin in which five children had congenital sensorineural hearing loss, dystopia canthorum (blepharophimosis which resulting from lateral displacement of the inner canthi), and leucism (Partial loss of pigmentation of the skin and hair) manifested as white hairlock or poliosis of the eyebrows [20]. Leonardi (1931) reported the association of heterochromia iridum and dystopia canthorum in a 4-year old boy (Figure 4). The mother of the boy milder condition [21]. John (1934) reported a nine year-old girl with total heterochromia, a partial sector-like heterochromia in the right eye of her younger sister, and an aunt with very light blue eyes; three members of a 3-generation family with dystopia canthorum [22]. In 1947, Swiss ophthamologist David Klein (1908-1993) reported a patient with a variant of Van der Hoeve-Waardenburg syndrome associated with bilateral deafness, pigmentation deficiencies, characteristic facial features and severe malformation of the arms [23].

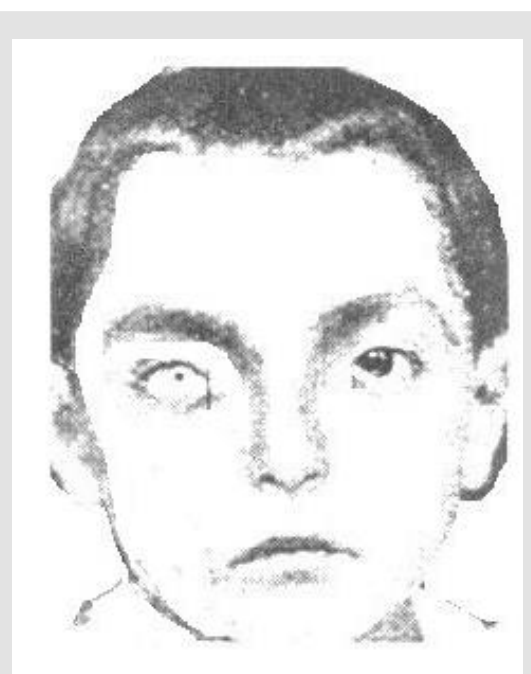

Figure 4: A sketch of the boy reported by Leonardi (1931) who had heterochromia iridum and dystopia canthorum.

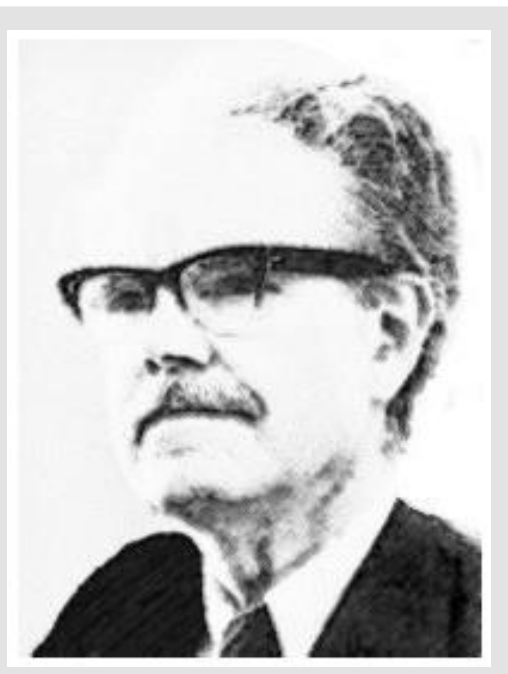

Figure 5: Petrus Johannes Waardenburg (1886-1979), Dutch ophthalmologist and geneticist.

In1951, Petrus Johannes Waardenburg (Figure 5) studied 840 patients with hearing loss from five Dutch institutes for the deafness and found 12 cases of the syndrome. Waardenburg confidently emphasized the emergence of a new syndrome, and described it as including [17]: 
1. Dystopia canthorum (Telecanthus)/broad, high nasal root (Hypertelorism).

2. Partial or total heterochromia iridum.

3. Congenital deafness or partial (unilateral) deafness.

4. Circumscribed albinism of the frontal head hair (white forelock).

\section{References}

1. Al-Mosawi AJ (2016) Mostyn Embrey syndrome. (1 $1^{\text {st }}$ Edn.)., LAP Lambert Academic Publishing, Saarbrücken, Germany.

2. Al-Mosawi AJ (2016) Congenital Chevalier Jackson syndrome. (1 ${ }^{\text {st }}$ Edn.)., LAP Lambert Academic Publishing, Saarbrücken, Germany.

3. Al-Mosawi AJ (2017) Unilateral Renal Agenesis and the Awareness of Mostyn Embrey Syndrome. Journal of Renal Medicine 1(1): 1-4.

4. Al-Mosawi AJ (2019) The Twenty Eighth Case of Congenital Chevalier Jackson. Annals of Clinical Case Reports 4: 1-4.

5. Al-Mosawi AJ (2019) The Case Number 104 of Sanjad Sakati Richardson Kirk Syndrome. Journal of Research Notes 2(2): 1-3.

6. Al-Mosawi AJ (2011) Rare genetic disorders in Iraq. (Ed). LAP Lambert Academic.

7. Al-Mosawi AJ (2019) Genetic and Hereditary Disorders in Iraqi Children. Ann Med \& Surg Case Rep 1(2): 1-8.

8. Al-Mosawi AJ (2020) Clinical Genetics and Dysmorphology: Our Extraordinary Experiences. SunKrist Journal of Neonatology and Pediatrics 2(1): 1-10.

9. Al-Mosawi AJ (2020) Uncommon and Rare Pediatric Syndromes Associated with Surgical Conditions in Iraqi Children. Global Journal of Surgery and Surgical Techniques 2(1): 1-8.

10. Al-Mosawi AJ (2018) The Uncommon and Rare Genetic Disorders in Iraq ( $1^{\text {st }}$ Edn.)., LAP Lambert Academic Publishing, Saarbrücken, Germany.

11. Al-Mosawi AJ (2020) Rare and uncommon genetic diseases in Iraq (French edition). Editions Our Knowledge.

ISSN: 2574-1241

DOI: 10.26717/BJSTR.2020.32.005187

Aamir Jalal Al Mosawi. Biomed J Sci \& Tech Res

(C) (i) This work is licensed under Creative BY Commons Attribution 4.0 License

Submission Link: https://biomedres.us/submit-manuscript.php
12. Al-Mosawi AJ (2020) Clinical genetics and dysmorphology: A unique pioneering experiences. ( $1^{\text {st }}$ Edn.). LAP Lambert Academic Publishing, Saarbrücken, Germany.

13. Al-Mosawi AJ (2020) Clinical Genetics and Dysmorphology: A Unique Breakthrough Experience (German Edition). Publishing house our knowledge.

14. Al-Mosawi AJ (2020) Gclinical genetics and dysmorphology: A unique pioneering experience (Italian Edition). Sapienza Editions.

15. Al-Mosawi AJ, Fewin L (2009) The first case of Niikawa-Kuroki syndrome in Kazakhstan associated with café au lait spots. G Ital Dermatol Venereol 144(5): 613-615.

16. Van Der Hoeve J (1916) Abnormal length of tear tubes with ankyloblepharon. Klin Mbl Augenh 56: 232-238.

17. Waardenburg PJ (1951) A new syndrome combining developmental anomalies of the eyelids, eyebrows and nose root with pigmentary defects of the iris and head hair and with congenital deafness. Am J Hum Genet 3(3): 195-253.

18. Hammerschlag V (1907) To the knowledge of the hereditar-degenerative deaf-dumbness. v. On pathological eye findings in the deaf and mute and their differential diagnostic significance 54: 18-36.

19. Urbantschitsch E (1910) On the aetiology of the deaf and dumb. In Hinsberg's Verh. Deut otol Ges Jena 350: 153-159.

20. Mende I (1926) About a family of hereditary-degenerative deaf-mutes with a mongoloid impact and partial leukism of the skin and hair. Arch. Kinderh 79: 214-222.

21. Leonardi $\mathrm{E}$ (1931) On the abnormal length of the lacrimal canaliculi and on some variations of position and width of the rhyme and of the nasal root. Boll Ocul 10: 165-190.

22. John I (1934) Contribution to the inheritance of congenital uncomplicated blepharophimosis. Arch Ophth Berl 133: 60-66.

23. Klein D (1947) Partial albinism (leucism) accompanies overdimutitis, osteomyodysplasia, multiple congenital joint stiffness and other congenital malformations. Arch Julius Klaus Stift 22: 336-342.

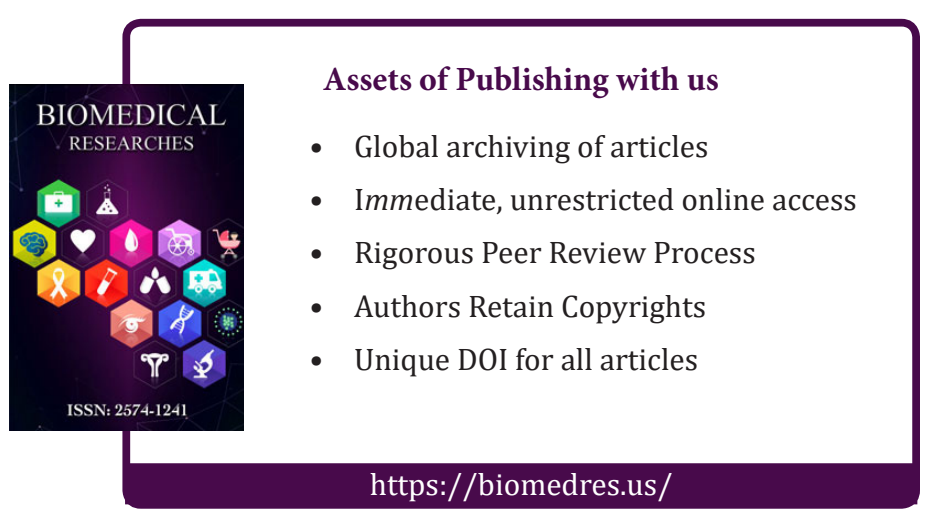

